\title{
CONSTRUCTIVIST BELIEFS OF LATVIAN MATHEMATICS TEACHERS: LOOKING INTO FUTURE
}

\author{
Ol̦esja Šapkova \\ Daugavpils University, Latvia
}

\begin{abstract}
The aim of the research is to clarify the profile of constructivist/traditional beliefs sustained by the mathematics teachers in Latvia. The research sample comprised 390 mathematics teachers representing all regions of Latvia. The present study is part of an international research within the NorBa project "Nordic-Baltic comparative research in mathematics education" that makes use of a quantitative questionnaire elaborated by project participants. The initial results show that the beliefs of Latvian teachers of mathematics on efficient teaching are oriented more towards a constructivist approach, yet there exist significant differences of teachers of different social and demographical groups in their beliefs on approaches in teaching and effective instruction. The obtained results provide a possibility to develop pre-service teacher education and teachers' professional development courses in order to assure sustainability of the learning process.
\end{abstract}

Key words: teachers, beliefs, teaching of mathematics, constructivist beliefs, traditional beliefs

\section{Introduction}

At the end of the 20th century, behaviourism-based theories of teaching were no longer efficiently functional for securing social demands set for the younger generation due to globalization, rapid development of technologies and information media and their active implementation in the life of each individual. Therefore, the year of 2000 became a turning point in mathematics education in many countries as new constructivism-based standards in mathematics were adopted. Besides, in order to deal with the urgent issues in mathematics in a comprehensive way, the European Union structural fund National programme "Improvement of the Quality of Learning in Natural Sciences, Mathematics and Technologies Subjects in Secondary Education" project "Elaboration of the Content of Learning and Teacher Further Education in the Subjects of Natural Sciences, Mathematics and Technologies" was carried out in Latvia from 2005 to 2008. Project staff, experts in their work, attempted to change the education philosophy in schools from 
- $\quad$ providing knowledge to learners' acquisition of skills of learning;

- $\quad$ scientific knowledge and algorithms to learners' own discoveries and skills;

- a passive to an active participation of learner in the process of learning;

- $\quad$ teacher as a provider of knowledge to teacher as an adviser and counsellor.

From 2008 until 2011, a similar project was implemented in natural sciences and mathematics education in basic school (Forms 7-9).

This study seeks to clarify the profile of constructivist/traditional beliefs of contemporary mathematics teachers of Forms 7-9 mathematics in Latvia. In this context, beliefs comprise an individual's subjective knowledge of a certain object or concern that may not necessarily be based on objective considerations (Pehkonen, 1994). The profile of beliefs is important because it is a filter that affects decision making of teachers more than their pedagogical knowledge or guidelines of academic programmes (Clark \& Peterson, 1986); therefore, even the best planned education reform may not lead to desirable outcomes if teachers' system of beliefs is not compatible with it.

\section{Theoretical framework}

Beliefs play an important role in many aspects of teaching. They are involved in helping individuals make sense of the world, influencing how new information is perceived and whether it is accepted or rejected. Beliefs colour memories with their evolution and judgment, and serve to frame our understanding of events (Borg, 2001). It is essential to differentiate between two kinds of beliefs: 1) exposed beliefs (what is said?) and 2) beliefs-inaction (what is done?). This study highlights the definitions teachers' exposed beliefs.

The term "teachers' beliefs" is generally used to single out the beliefs that are associated with and relevant to an individual's teaching. The majority of scholars agree on the following differentiation of teachers' beliefs:

- $\quad$ beliefs about teaching, learning, and learners (the focus of the present article);

- beliefs about subject matter;

- beliefs about self as a teacher;

- beliefs about the role of a teacher (Calderhead, 1995).

Teachers' exposed beliefs their own capabilities guide their teaching practices (Kagan, 1992; Pajares, 1992; Ball, 1996; Handal \& Herington, 2003) and the implementation of curriculum reform (Handal \& Herrington, 2003). At the classroom level, teacher's beliefs can enhance curriculum reform (Burkhardt, Fraser, \& Ridgway, 1990; Sosniak, Ethington, \& Varelas, 1991; Koehhler \& Grouws, 1992; Sosniak, Ethington, \& Varelas, 1991).

There exist different approaches to studying teachers' beliefs on teaching. One of them investigates whether teachers' beliefs are in harmony with the reforms of the process of teaching mathematics (Aguirre, 2009). These studies prove the existence of two types of teachers, traditional and innovative, with their corresponding types of instruction.

1. Traditional transmission instruction is based on a theory of learning that suggests that students will learn facts, concepts and understandings by absorbing the content of their teacher's explanations or by reading explanations from a text and 
answering related questions. Skills are mastered through guided and repetitive practice of each skill in sequence, in a systematic and highly prescribed fashion and done largely independent of complex applications in which those skills might play some role.

2. Constructivist-compatible instruction is based on a theory of learning that suggests that understanding arises only through prolonged engagement of the learner with relating new ideas and explanations to the learner's own prior beliefs. A corollary of that assertion is that the capacity to employ skills comes only from experience in working with concrete problems that provide experience in deciding how and when to call upon each of a diverse set of skills (Ravitz, Becker, \& Wong, 2000).

One of the first studies on teachers' beliefs about teaching, learning, and learners was conducted in the USA in 1998 within the framework of the national poll "TLC-1998 Teaching, Learning and Computing". Differences were located in teachers' beliefs that may be differentiated in several groups (for instance, according to the education syllabus, the subject taught and gender). The teachers whose responses were described in this study numbered 4083, including 2251 in the Fsinational probability sample of schools. The studied teachers taught students in Forms 4 to 12 different subjects containing mathematics. The teachers selected for the survey were disproportionately oversampled as they made substantial use of computers, had students doing project work and emphasized higher-order thinking in the teaching and learning process.

There are also studies specifically focused on mathematics teachers' beliefs on teaching. The purpose of an Australian study was to determine whether mathematics teachers' beliefs and practices could be characterized in terms of behaviourist and constructivist dimensions (Handal, 2003). The focus of the study was the Standard course, which is a syllabus with a mandatory thematic component (Board of Studies New South Wales, 1996; Handal, 2000). The data analyses reveal the existence of two curricular orientations in teachers' instructional beliefs and practices. These two orientations are similar to the constructivist and behaviourist approaches to teaching and learning mathematics. It was found out that the constructivism-oriented teachers have a more favourable attitude towards the thematic approach than the behaviourism-oriented teachers.

TALIS (Teacher Questionnaire: Teaching Practices, Beliefs and Attitudes Module) survey results (OECD, 2009) demonstrated that endorsement of constructivists' beliefs is stronger than that of traditional beliefs in most countries. Teachers in North-Western Europe and Scandinavia showed a stronger preference for constructivist views than teachers in Southern Europe. Preferences of teachers in East-European countries can not be identified as traditional or constructivism based.

Hirsch (1996) argues that, influenced by colleges of teacher education where Deweyan world-views have predominated for many decades, most teachers, particularly elementary teachers, adopt a constructivist philosophy. Becker and Riel (1999) argue that teachers' philosophies are largely constructivist but that the school bureaucratic culture and public expectations for measurable documentation of student "achievement" severely constrain most teachers from implementing constructivist pedagogy in daily practice. 
This paper also focuses on the possible traditional and constructivist beliefs of mathematics teachers on the teaching approach in their classroom. The following research questions were set taking into consideration the literature review:

1. Which approach to learning (traditional or constructivist) is preferred by mathematics teachers in Latvia in their beliefs on teaching approach?

2. What are the differences, if any, between the beliefs on teaching approaches of mathematics teachers in Latvia and the USA?

3. What statistically significant differences, if any, are among the beliefs on teaching approaches of teachers belonging to different socio-demographical groups?

\section{Method}

\section{Instrument}

The present research is a part of an international comparative study NorBa project "NordicBaltic Comparative Research in Mathematics Education" which uses a quantitative questionnaire elaborated by project participants. The questionnaire is divided into eight parts, seven of which are quantitative and entail 77 statements that, with the exception for part A, are evaluated according to a 5 or 4 point Likert scale from 'fully agree' to 'fully disagree'. The questionnaire parts are as follows: A. Basic information; B. Your general satisfaction with your work as a teacher; C. Your beliefs on two approaches to teaching; D. Your beliefs on efficient/good teaching; E. Your beliefs on efficient/good teaching and learning of mathematics; F. How do you use textbooks? G. Your habitual action in class.

\section{Sample}

The sampling of mathematics teachers of Forms 7-9 consisted of 390 mathematics teachers from different regions of Latvia; 96 of them work in schools with ethnic minorities, 13 are males and 165 are teachers working in bigger towns, while 225 are teachers who work in rural settlement and small town schools.

The sample includes teachers of different ages, education level and teaching experience. The average age of respondents is 47 with range from 25 to 74 years old; the sampling is dominated by the age group from 40 to 49 (more than $43 \%$ of respondents). The average duration of teaching experience of respondents is from 26 to 30 years (more than $23 \%$ of respondents). The respondents have taught mathematics in Forms 7-9 for 19 years on average, with range from one year to 44 years. The majority of respondents hold a bachelor's degree. More than $47 \%$ of teachers hold a master's degree (Table 1).

This research sample represents the distribution of mathematics teachers in Forms 7-9 in Latvia. According to the data of the Ministry of Education of Latvia, 94\% of mathematics teachers are female, $32 \%$ of all teachers work in schools for ethnic minorities and $60 \%$ of all teachers work in small towns and rural settlements, with $36 \%$ of all teachers working 
in Riga and its region, $18 \%$ - in Latgale, 16\% - in Kurzeme and Zemgale and 14\% - in Vidzeme.

Table 1. Socio-demographic indices of teachers' sample $(n=390)$

\begin{tabular}{|c|c|c|c|c|}
\hline Characteristics & & Frequency N (\%) & Valid frequency & p value* \\
\hline \multirow{5}{*}{ Region of Latvia } & Riga and its region & $151(38.7 \%)$ & & \multirow{5}{*}{0.000} \\
\hline & Latgale & $95(24.4 \%)$ & & \\
\hline & Vidzeme & $62(15.9 \%)$ & & \\
\hline & Kurzeme & $48(12.3 \%)$ & & \\
\hline & Zemgale & $34(8.7 \%)$ & & \\
\hline \multirow{2}{*}{ Sex } & Female & $377(96.7 \%)$ & & \multirow[t]{2}{*}{0.000} \\
\hline & Male & $13(3.3 \%)$ & & \\
\hline \multirow{2}{*}{$\begin{array}{l}\text { Education pro- } \\
\text { gramme }\end{array}$} & General & $294(75.4 \%)$ & & \multirow[t]{2}{*}{0.000} \\
\hline & Ethnic minorities & $96(24.6 \%)$ & & \\
\hline \multirow{2}{*}{ Urbanization } & Bigger town & $165(42.3 \%)$ & & \multirow{2}{*}{0.002} \\
\hline & Small town or rural & $225(57.7 \%)$ & & \\
\hline \multirow{5}{*}{ Age } & $20-29$ & $11(2.8 \%)$ & & \multirow{5}{*}{0.000} \\
\hline & $30-39$ & $62(15.9 \%)$ & & \\
\hline & $40-49$ & $171(43.8 \%)$ & & \\
\hline & $50-59$ & $127(32.6 \%)$ & & \\
\hline & $60+$ & $19(4.9 \%)$ & & \\
\hline \multirow{4}{*}{ Education } & Secondary & $4(1 \%)$ & $4(1 \%)$ & \multirow{4}{*}{0.000} \\
\hline & Bachelor's degree & $198(50.2 \%)$ & $198(50.9 \%)$ & \\
\hline & Master's degree & $186(47.7 \%)$ & $186(47.8 \%)$ & \\
\hline & Doctoral degree & $1(0.3 \%)$ & $1(0.3 \%)$ & \\
\hline \multirow{9}{*}{$\begin{array}{l}\text { Teaching experi- } \\
\text { ence in years }\end{array}$} & $0-5$ & $12(3.1 \%)$ & & \multirow{9}{*}{0.000} \\
\hline & $6-10$ & $21(5.4 \%)$ & & \\
\hline & $11-15$ & $43(11.0 \%)$ & & \\
\hline & $16-20$ & $67(17.2 \%)$ & & \\
\hline & $21-25$ & $77(19.7 \%)$ & & \\
\hline & $26-30$ & $92(23.6 \%)$ & & \\
\hline & $30-35$ & $44(11.3 \%)$ & & \\
\hline & $36-40$ & $28(7.2 \%)$ & & \\
\hline & $41+$ & $6(1.5 \%)$ & & \\
\hline
\end{tabular}

* Group differences were assessed with Chi-square tests

\section{Procedure}

The data collecting process took place in October - December 2010 at several stages:

1. Informative e-mails were sent to schools all over Latvia inviting mathematics teachers to participate in the polling.

2. Teachers who wished to participate in the polling filled in applications electronically and sent them to a specially appointed e-mail address.

3. The registered participants of the polling were provided a code and they were sent questionnaires with the necessary instructions.

4. Respondents filled in questionnaires and sent them to the appointed e-mail address. 
Participation in the polling was voluntary; respondents' identity and records were kept confidential: the report did not disclose teachers' personal data (name, school).

\section{Data analysis}

The following methods of statistical analysis were used for data processing: KolmogorovSmirnov test to assess distribution of data, Descriptive Statistics, Frequencies, Correlation, Cluster Analysis, Mann-Whitney criterion and Kruskall-Wallace criterion, as well as Cronbach Alpha, to assess the reliability of scale. Justification as to the relevance and appropriateness of the statistical techniques are detailed below.

\section{Main results}

In accordance with the aim of the article and questions set for the research, only the results of part $\mathrm{C}$ of the questionnaire were analysed. This part $\mathrm{C}$ was constructed guided by the specific part of the aforementioned USA-based research "TLC-1998 Teaching, Learning, and Computing" (1998): it was translated from English to Latvian and Russian.

In this part of the questionnaire the teachers were offered a description of two teachers with competing approaches in teaching, as described below. One of them poses the teacher as a facilitator of student learning who provides opportunities and resources for students to discover or construct knowledge for themselves; the other describes the teacher's role as one who explains knowledge in a structured manner (Ravitz, Becker, \& Wong, 2000).

Ms Kalnina was conducting her class in an animated way, asking questions that students could answer quickly based on the reading they had done the day before. After this review, Ms Kalnina taught the class new material, again using simple questions to keep students attentive and listening to what she had said.

Ms Bērzina's class was also having a discussion, but many of the questions came from students themselves. Though Ms Bèrzing would clarify students' questions and suggest where the students could find relevant information, she didn't really answer most of the questions herself.

Utilizing a Likert scale, the four questions were posed.

- $\quad \mathrm{C} 1$. Which type of class discussion would you be more comfortable having in class?

- $\quad$ C2. Which type of discussion do you think most students prefer to have?

- $\quad$ C3. From which type of class discussion do you think students gain more knowledge?

- $\quad$ C4. From which type of discussion do you think students gain more useful skills? 
The questions were posed with the five options of reply: 1) certainly in Ms Kalnina's class; 2) more in Ms Kalniņa's class; 3) cannot say; 4) more in Ms Bērziña’s class; 5) certainly in Ms Bērziña's class.

\section{Teachers' orientations towards teaching approaches}

To assess the reliability of the scale, Cronbach Alpha coefficient was calculated with the value 0.688 . Thus, it may be concluded that reliability level of part $\mathrm{C}$ of the questionnaire is average and part $\mathrm{C}$ may be used in the research.

Descriptive statistics shows that all questions have a similar range $(R=4)$, the biggest $(\mathrm{Max}=5)$ and the smallest (Min=1) value. Consequently, it evidences that all response options were chosen at least once. The mean of all questions $\mathrm{M}=3.16$, the common standard deviation $\mathrm{SD}=1.21$. Question $\mathrm{C} 4$ (Students gain more useful skills) has the highest mean $(\mathrm{M}=3.68, \mathrm{SD}=1.13)$ while $\mathrm{C} 2$ (Teachers think students prefer) - the lowest one $(\mathrm{M}=2.91$, $\mathrm{SD}=1.17$ ) (Table 2).

Table 2. Descriptive statistics on mathematics teachers supporting either traditional or constructivist approach to teaching

\begin{tabular}{lcccc}
\hline Questions & $\begin{array}{c}\text { Mean } \pm \text { Std. Devia- } \\
\text { tion }\end{array}$ & $\begin{array}{c}\text { Traditional ap- } \\
\text { proach (\%) }\end{array}$ & $\begin{array}{c}\text { Middle position } \\
(\%)\end{array}$ & $\begin{array}{c}\text { Constructivist } \\
\text { approach (\%) }\end{array}$ \\
\hline $\begin{array}{l}\text { C1 Teachers would } \\
\text { be more comfort- } \\
\text { able with }\end{array}$ & $2.92 \pm 1.27$ & 47.1 & 11.1 & 41.7 \\
\hline $\begin{array}{l}\text { C2 Teachers think } \\
\text { students prefer }\end{array}$ & $2.91 \pm 1.17$ & 42.2 & 21.6 & 36.0 \\
\hline $\begin{array}{l}\text { C3 Students gain } \\
\text { more knowledge }\end{array}$ & $3.14 \pm 1.28$ & 36.9 & 15.9 & 46.9 \\
\hline $\begin{array}{l}\text { C4 Students gain } \\
\text { more useful skills }\end{array}$ & $3.68 \pm 1.14$ & 20.5 & 11.5 & 67.7 \\
\hline
\end{tabular}

Further, Table 2 reveals how often teachers choose traditional approach in their replies (options $1+2$ ), how often they choose constructivist approach (options 4+5) and how often they could not answer the question or choose middle position (option 3 ).

In response to question $\mathrm{C} 1$ (Teachers would be more comfortable with), there was the smallest number of teachers who could not determine their position and the largest number $(41.7 \%)$ of those who supported the traditional approach. In response to question C4 (Students gain more useful skills), the largest number of teachers supported the constructivist approach $(67.7 \%)$. As both indices differ for more than $20 \%$, this suggests that teachers who first selected the traditional approach providing answer to question $\mathrm{C} 1$ changed over to constructivist approach providing answer to question C4. Most teachers could not determine their position $(21.6 \%)$ in answers to question C2 (Teachers think students prefer). At the same time, the smallest number of teachers supported a constructivist approach, namely, in $\mathrm{C} 2$ question. 
Spearman's correlation was used for correlation analysis as the data do not have a normal distribution. It shows that all questions have a statistically significant correlation. The closest relation exists between questions $\mathrm{C} 1$ and $\mathrm{C} 3(\mathrm{r}=0.61, \mathrm{p}<0.01), \mathrm{C} 3$ and $\mathrm{C} 4$ $(\mathrm{r}=0.52, \mathrm{p}<0.01)$, and $\mathrm{C} 1$ and $\mathrm{C} 4(\mathrm{r}=0.50, \mathrm{p}<0.01)$. Less close correlation exists between question $\mathrm{C} 2$ and other questions (refer to Table 3 ).

Table 3. Intercorrelations of the teachers' feelings of comfort, students' priorities and discussions in knowledge acquisition and developing useful skills $(n=390)$

\begin{tabular}{cccc}
\hline Questions & $\begin{array}{c}\text { C1 Teachers would be } \\
\text { more comfortable with }\end{array}$ & $\begin{array}{c}\text { C2 Teachers } \\
\text { think students } \\
\text { prefer }\end{array}$ & $\begin{array}{c}\text { C3 Students gain } \\
\text { more knowledge }\end{array}$ \\
\hline $\mathrm{C} 2$ & $0.205^{* *}$ & & \\
\hline $\mathrm{C} 3$ & $0.612^{* *}$ & $0.115^{*}$ & \\
\hline $\mathrm{C} 4$ & $0.503^{* *}$ & $0.166^{* *}$ & $0.515^{* *}$ \\
\hline${ }^{* *} \mathrm{p}<0.01 ;{ }^{*} \mathrm{p}<0.05$ & &
\end{tabular}

\section{Latvian and US teachers: Traditional or constructivist approach}

Tables of frequency provide an opportunity to compare the results of Latvian case with those of the analogous US research (Ravitz, Becker, \& Wong, 2000) (Tables 4, 5, 6 and 7). Apart from teachers' beliefs about what students prefer (Table 4), it is obvious that teachers of the presented sample in Latvia are more tended to constructivist approach than teachers of the similar study in the USA.

Table 4. Replies of US and Latvian teachers about what they would be more comfortable with in teaching

\begin{tabular}{cccc}
\hline Country & Traditional approach & Middle position & Constructivist approach \\
\hline USA & $64 \%$ & $7 \%$ & $28 \%$ \\
\hline Latvia & $47 \%$ & $11 \%$ & $42 \%$ \\
\hline
\end{tabular}

The least differences in replies of US and Latvian teachers about the approach to learning that most develops learners' knowledge were observed (Table 5).

Table 5. Replies of US and Latvian teachers about the teaching approach they suppose students prefer

\begin{tabular}{cccc}
\hline Country & Traditional approach & Middle position & Constructivist approach \\
\hline USA & $53 \%$ & $10 \%$ & $37 \%$ \\
\hline Latvia & $42 \%$ & $24 \%$ & $34 \%$ \\
\hline
\end{tabular}

Analysing the replies of US and Latvian teachers about the approach to learning that most develops learners' skills, it is possible to state that the majority of teachers in both groups support constructivist approach (Table 6). 
Table 6. Replies of US and Latvian teachers about the approach to learning that most develops learners' knowledge

\begin{tabular}{cccc}
\hline Country & Traditional approach & Middle position & Constructivist approach \\
\hline USA & $44 \%$ & $14 \%$ & $42 \%$ \\
\hline Latvia & $37 \%$ & $16 \%$ & $47 \%$ \\
\hline
\end{tabular}

Table 7. Replies of US and Latvian teachers about the approach to learning that most develops learners' skills

\begin{tabular}{cccc}
\hline Country & Traditional approach & Middle position & Constructivist approach \\
\hline USA & $29 \%$ & $14 \%$ & $57 \%$ \\
\hline Latvia & $20,5 \%$ & $11,5 \%$ & $68 \%$ \\
\hline
\end{tabular}

Apart from teachers' beliefs about what students prefer, it is obvious that the teachers of the presented sample in Latvia are more tended to constructivist approach than the teachers of a similar study in the USA.

\section{Mathematics teachers' beliefs on teaching approaches: Socio-demographic differences}

According to Kolmogorov-Smirnov criterion, in all questions, it was revealed that there are significant differences with normal distribution, therefore the analysis of differences between socio-demographic groups was produced by using non-parametric criterion. To make out whether there exist statistically significant differences in the beliefs of teachers representing diverse socio-demographical groups concerning teaching approaches, and if they do, in what groups they exist, each question $(\mathrm{C} 1, \mathrm{C} 2, \mathrm{C} 3, \mathrm{C} 4)$ was cross-tabulated considering all socio-demographical characteristics. The following statistically significant results were gained.

Question C1 (Teachers would be more comfortable) brings out essential differences $(\mathrm{p}=0.030)$ among the replies of teachers from diverse regions of Latvia. Trend towards constructivism is slightly more expressed in Riga's region and in Latgale. There exist statistically significant differences $(\mathrm{p}=0.000)$ among teachers of general education and ethnic minorities programmes, teachers who work in rural settlements and bigger towns $(p=0.007)$ and among groups of education $(\mathrm{p}=0.000)$ : absolute frequency exceeds the expected frequency for traditional approach to teaching for teachers who work in schools with the general basic education programme, in rural settlements or small towns and teachers holding a bachelor's degree. However, absolute frequency exceeds the expected frequency in constructivist approach to teaching for teachers working in ethnic minority schools, bigger towns and those holding a master's degree. Very high $(\mathrm{p}=0.001)$ and maximally high $(\mathrm{p}=0.000)$ statistical differences are observed according to age group and teaching experience subgroups: with growing of age and teaching experience there occurs a growth in positive attitude towards constructivist approach to teaching in class. 
In question C2 (Teachers think students prefer) no statistically significant differences among socio-demographical groups are observed.

Question C3 (Students gain more knowledge) reveals maximal significant differences $(\mathrm{p}=0.000)$ depending on the education programme and very significant differences depending on teachers' place of residence $(\mathrm{p}=0.034)$. Teachers working in ethnic minority schools and bigger towns show more distinctly constructivist beliefs. Besides there are statistically significant differences also in regions of Latvia $(\mathrm{p}=0.017)$ : teachers in Vidzeme express more traditional beliefs, while teachers in Latgale - constructivist. Statistically significant differences $(\mathrm{p}=0.030)$ with orientation to constructivist approach are observed in teaching experience groups from 16 to 20 and from 31 to 35 years. In question C4 (Students gain more useful approach), there exist statistically significant differences $(p=0.000)$ between teachers of general and ethnic minority education programmes in question $\mathrm{C} 1$ and groups of education $(\mathrm{p}=0,004)$. The same as with question $\mathrm{C} 1$ (Teachers would be more comfortable) constructivist approach is more popular with teachers working in ethnic minority schools and those holding a master's degree.

To determine differences in teachers' approaches on teaching mathematics depending on education programme, urbanization and mathematics as a major subject, Mann-Whitney criterion was used. Statistically significant differences were revealed among groups of teachers in diverse education programmes (items $\mathrm{C} 1, \mathrm{C} 3$ and $\mathrm{C} 4, \mathrm{p}=0.000$ ) and depending on their place of residence (item $\mathrm{C} 1, \mathrm{p}=0.007$ ). To clarify the character of the above mentioned differences, the mean values of these questions were compared in the corresponding groups (Tables 8 and 9).

Table 8. Comparison of teachers' mean values in the group "Education programme"

\begin{tabular}{lccc}
\hline Education programme & $\begin{array}{c}\text { C1Teachers would } \\
\text { be more comfortable }\end{array}$ & $\begin{array}{c}\text { C3 Students } \\
\text { gain more } \\
\text { knowledge }\end{array}$ & $\begin{array}{c}\text { C4 Students } \\
\text { gain more } \\
\text { useful ap- } \\
\text { proach }\end{array}$ \\
\cline { 2 - 4 } & $\begin{array}{c}\text { Mean } \pm \text { Std. Devia- } \\
\text { tion }\end{array}$ & $\begin{array}{c}\text { Mean } \pm \text { Std. } \\
\text { Deviation }\end{array}$ & $\begin{array}{c}\text { Mean } \pm \text { Std. } \\
\text { Deviation }\end{array}$ \\
\hline General education programme & $2.64 \pm 1.20$ & $2.89 \pm 1.24$ & $3.54 \pm 1.12$ \\
\hline Ethnic minorities education programme & $3.76 \pm 1.08$ & $3.90 \pm 1.11$ & $4.09 \pm 1.09$ \\
\hline
\end{tabular}

Table 9. Comparison of teachers' mean values in the group "Urbanization" (question C1)

\begin{tabular}{lc}
\hline Teachers' place of residence & Mean \pm Std. Deviation \\
\hline Rural settlements and small towns & $2.77 \pm 1.23$ \\
\hline Riga and bigger towns & $3.12 \pm 1.28$ \\
\hline Total & $2.92 \pm 1.27$ \\
\hline
\end{tabular}

Similar results gained by means of factor analysis also verify the validity of data. KruskallWallace criterion was used to locate differences between teachers' two approaches to teaching mathematics depending on the region of Latvia, teachers' education, age and teaching experience. It was revealed that there exist statistically significant differences depending on 
the region (items $\mathrm{C} 3, \mathrm{p}=0.008$ and $\mathrm{C} 1, \mathrm{p}<0.05)$, teachers' age and teaching experience $(\mathrm{C} 1$, $\mathrm{p}<0.01)$ and education $(\mathrm{C} 1, \mathrm{p}=0.000$ and $\mathrm{C} 4 \mathrm{p}<0.05)$. Like in the case of using cross-tables, constructivist approach in the above mentioned questions is more popular with teachers from Latgale and Riga, those with greater teaching experience and age as well as teachers holding a master's degree.

Cluster analysis with k-means cluster analysis method and 4 cluster limitation made it possible to divide all respondents in 4 groups/clusters (Table 10).

Table 10. Mean values of questions C1, C2, C3, C4 in 4 clusters according to the teachers' beliefs on two teaching approaches

\begin{tabular}{lcccc}
\hline & $\begin{array}{c}\text { Cluster 1 } \\
(\mathbf{n}=97)\end{array}$ & Cluster 2 (n=103) & $\begin{array}{c}\text { Cluster 3 } \\
(\mathbf{n}=\mathbf{8 0})\end{array}$ & $\begin{array}{c}\text { Cluster 4 } \\
(\mathbf{n = 1 0 8})\end{array}$ \\
\hline $\begin{array}{l}\text { C1 Teachers would be } \\
\text { more comfortable }\end{array}$ & 4.2 & 3.4 & 1.6 & 2.2 \\
\hline $\begin{array}{l}\text { C2 Teachers think stu- } \\
\text { dents prefer }\end{array}$ & 4.0 & 1.9 & 1.9 & 3.6 \\
$\begin{array}{l}\text { C3 Students gain more } \\
\text { knowledge }\end{array}$ & 4.2 & 4.0 & 2.0 & 2.3 \\
$\begin{array}{l}\text { C4 Students gain more } \\
\text { useful skills }\end{array}$ & 4.2 & 4.3 & 2.2 & 3.7 \\
\hline
\end{tabular}

Table 2 shows that group 1 includes the teachers who are oriented towards constructivism. Group 2 holds the teachers who are basically oriented towards constructivism; they consider that their learners would not like a constructivist approach in lessons. Group 3 holds the teachers who are oriented towards conventional methods and approaches. Group 4 holds basically traditionally oriented teachers who still consider that their learners would prefer and find more useful teaching of the new, constructivist kind.

\section{Discussion}

The initial results show that the beliefs of Latvian teachers of mathematics on efficient teaching are more inclined towards a constructivist approach. This is proved first of all by the mean of all questions. However, it must be noted that, though the majority of teachers realize that a new kind of teaching provides learners with more knowledge and useful skills, the teachers do not feel comfortable when conducting classes with the new approach.

Both the results of using cross-tables and Mann-Whitney criterion make it possible with a high degree of probability to state statistically significant differences in the group of ethnic minority/general education programme: teachers of mathematics in ethnic minority schools tend more toward the constructionist approach as compared to their colleagues in general education schools. This fact is ascertained by the results of cluster analysis $(\mathrm{p}=0.000)$ in which $33.3 \%$ of ethnic minority school teachers belong to the cluster of constructivist oriented teachers and just $9.4 \%$ of ethnic minority school teachers prefer traditional teaching approach. In comparison to teachers who work in schools of general education, the respective percentage is $22.3 \%$ and $24.3 \%$. 
Concerning other groups, irrespective of the fact that in different analyses statistically significant results were gained, no concrete conclusions may be made yet and additional tests are needed. First, it is related to the fact that in other groups there were no statistically significant results in cluster groups, second, because Cronbach Alpha value does not reach 0.7 , though in tests of attitudes and personality it may usually be lower.

Finally, the distribution of Latvian sample according to socio-demographical groups is not homogeneous: e.g., $87.5 \%$ of ethnic minority schools are located in Riga region and Latgale, $76 \%$ of ethnic minority schools are in Riga and bigger towns, $78.1 \%$ of ethnic minority school teachers hold a master's degree. This further education of the teacher may be one of the main reasons why ethnic minority school teachers have a greater inclination towards constructivism. In urban environment with more versatile culture and economic environment greater innovations are possible in education as well.

Except for the question that students gain more useful skills, values of all other questions slightly differ shifting to one or another side from the mean value 3 . This may signify that teachers in many cases take a third position that differs both from the traditional and constructivist approach, e.g. they prefer the formal approach. This hypothesis may be proved by analyzing parts $\mathrm{D}, \mathrm{F}$, and $\mathrm{G}$ of the questionnaire.

The present research is first of all oriented at espoused beliefs study, though it must be noted that the author of the research further intends to produce beliefs-in-action analysis and its comparison to espoused beliefs. The nature of the relationship between espoused beliefs and beliefs-in-action is important in deciding if it is better to concentrate upon the behaviour, the beliefs, or both in order to improve behaviour.

One more direction for a further research is to study why, with growing of age and teaching experience, a growth in positive attitude towards constructivist approach to teaching in class occurs, also why, in different regions of Latvia, there are different professional development opportunities. In order to achieve this, it is planned to use qualitative research methods, for instance, semi-structured interviews with educational politicians, teachers and higher education establishment staff and environment.

As mentioned above, the teachers of the presented sample in Latvia are more tended to constructivist approach than the teachers of the similar study in the USA. It means that exposed beliefs of Latvian teachers better match with reforms in mathematics education. In further studies there will be an opportunity to compare the obtained results on exposed beliefs of Latvian mathematics teachers with the exposed beliefs of teachers in Baltic and Nordic countries within NorBa project. Research on teachers' beliefs in different countries will allow identifying both, known and so far unknown, aspects.

\section{Conclusions}

The initial results show that Latvian mathematics teachers' beliefs on efficient teaching are tended towards the new/constructivist approach. There exist statistically significant differences among teachers representing different socio-demographical groups in their constructivist beliefs on teaching approaches: ethnic minority school teachers have a greater inclination towards constructivism. Teachers of Latvia are more tended towards constructivist 
approach than US teachers (according to 1998 national polling "TLC-1998 Teaching, Learning, and Computing"). The information gained in the course of the research provides an opportunity to develop the education of young teachers, teacher further education courses, to improve academic programmes as well as secures the sustainability of the process of education.

\section{References:}

Aguirre, J. (2009). Teacher domain specific beliefs and their impact on mathematics education reform. In J. Maa $\beta$ \& W. Schlöglmann (Eds.), Beliefs and attitudes in mathematics education: New research results (pp. 45-58). Rotterdam, the Netherlands: Sense.

Becker, H. J, \& Riel, M. M. (1999). Teacher role orientation: Classroom focus versus collaborative professional practice. Retrieved December 20, 1999, from http://www.crito .uci.edu/tlc/findings/

Board of Studies New South Wales. (1996). Mathematics standard course: Years 9-10. Sydney: Author.

Ball, D. L. (1996). Teacher learning and the mathematics reforms: What we think we know and what we need to learn. Phi Delta Kappan, 77, 500-508.

Borg, M. (2001). Teachers' beliefs. ELT Journal, 55(2), 186-188.

Burkhardt, H., Fraser, R., \& Ridgway, J. (1990). The dynamics of curriculum change. In I. Wirszup \& R. Streit (Eds.), Development in school mathematics education around the world (Vol. 2, pp. 3-29). Reston, VA: NCTM.

Calderhead, J. (1995). Teachers: Beliefs and knowledge. In D. C. Berliner \& R. C. Calfee (Eds.), Handbook of educational psychology. New York: Simon \& Schuster, Macmillan.

Clark, C. M., \& Peterson, P. L. (1986) Teachers' thought processes. In M. C. Wittrock (Ed.), Handbook of research on teaching (pp. 255-296). New York: Macmillan.

Handal, B. (2000). Teaching in themes: Is that easy? Reflections, 25(3), 48-49.

Handal, B. (2003). Constructivist and behaviourist teachers. International Online Journal of Mathematics and Science Education. Retrieved September 14, 2003, from http://www.upd.edu.ph/ ismed/online/articles/profiling/abstract.htm

Handal, B., \& Herrington, A. (2003). Mathematics teachers' beliefs and curriculum reform. Mathematics Education Research Journal, 15(1), 59-69.

Hirsch, E. D. (1996). The schools we need and why we don't have them. New York, NY: Doubleday.

Kagan, D. M. (1992). Implications of research on teacher belief. Educational Psychologist, 27, 65-90.

Koehler, M. S., \& Grouws, D. A. (1992). Mathematics teaching practices and their effects. In D. A. Grouws (Ed.), Handbook of research in on mathematics teaching and learning (pp. 115-126). New York: Macmillan.

OECD. (2009). Creating effective teaching and learning environments: First results from TALIS. Paris: OECD Publishing. 
Pajares, M. F. (1992). Teachers beliefs and educational research: Cleaning up a messy construct. Review of Educational Research, 62, 307-332.

Pehkonen, E. (1994). Teachers' and pupils' beliefs in focus - consequence of constructivism. In M. Ahtee \& E. Pehkonen (Eds.), Constructivist viewpoints for school teaching and learning in mathematics and science (pp. 27-33). Helsinki: University of Helsinki.

Ravitz, J. L., Becker, H. J., \& Wong, Y. T. (2000). Constructivist-compatible beliefs and practices among U.S. teachers (Report No. 4). Irvine, CA: Center for Researh on Information Technology and Organizations, University of California.

Sosniak, L. A., Ethington, C. A., \& Varelas, M. (1991). Teaching mathematics without a coherent point of view: Findings from the IEA Second International Mathematics Study. Journal of Curriculum Studies, 23, 119-131.

\section{Correspondence:}

Ol̦esja Šapkova, PhD student, Institute of Sustainable Education, Faculty of Education and Management, Daugavpils University, Parādes Street 1, LV-5401. Email: alesja.shapkova@ gmail.com 